\title{
The Parisian Porters' Revolt of January I786
}

\author{
BENNETT GILBERT
}

\begin{abstract}
This paper gives a full picture of the moral universe pressuring all sides in the strike by porters in Paris during January I786. These Parisian day-labourers found their livelihood taken away by a new system of parcel delivery, part of a many-sided endeavour to rationalise the economy. They rioted and were the first rioting mob to appeal to the king at Versailles. This paper looks at the riot from the points of view of the rioters and their neighbours, the police, the investors in the new parcel post scheme and the advancing American trade.
\end{abstract}

Keywords: French Revolution, crowd, riot, rationalisation, postal system

\section{I.}

On 2 January I786 several hundred Parisian day-labourers battered public officials and police with sticks in the Faubourg Saint-Marcel, and a fortnight later hundreds more marched to Versailles to petition Louis XVI. These actions were a profound response to ideas that threatened their well-being within a moral order. Such ideas, stemming from rationalised natural philosophy, suffused not only the intellectual class but also, though less directly, the entire society from forested Saint-Cloud to the famished ancient faubourgs, as rich, bourgeois and poor struggled to engage these new ideas, to stay alive and to organise their moral experience. The state's realisation of these ideas in several national projects and in the gestural shape of the brief, violent revolt of these oppressed, the fight given by the police, along with the affectless response of the court, show part of the story of moral experience, deliberation and choice as a quick flash in the anxiety of the years directly before the Revolution that began in July I789. ${ }^{\mathrm{I}}$

The following account sets the whole of this event - from its major actions down to its gestures and movements - within state and private structures, showing that both crowd and state were moral agents in the massive story of the rationalisation of life. This approach advances our understanding of pre-Revolution rioters and riots (and of politics more generally) beyond their 'moral economy' to a fuller view of their moral life.

II.

The debate as to whether the participants in crowd actions in France during the decades prior to the Revolution of $\mathrm{I} 789$ were a heroic and just people or felonious actors of cruel and evil deeds began in the divided responses of contemporaries. The probably pseudonymous J. Charron in a I 788 pamphlet about the bloody riots in April of that year held the middle position: some of the actors were good, some were bad; there was no alternative to the use of armed state force to restore order, but the police over-reacted; no one organised the riots, which were 'natural'; and the root cause was greed throughout the society, yielding a surfeit of luxe and leading to the decline of religion. ${ }^{2}$ 
At farther ends of the range of opinion were Edmund Burke (I729-I797), holding that the revolutionaries were miscreants deluded by ideology and by lust for power, ${ }^{3}$ and Jules Michelet (I798-I874), regarding the French people as a whole, a virtuous nation striving and suffering for its own freedom and for the betterment of mankind.

Charron was a little in advance of his time when, in the first part of his pamphlet, he attempted to pinpoint the 'motor' of the crowd as a whole. ${ }^{4}$ Was it people with bad intentions ('gens mal intentionnés')? Or intellectuals ('des intelligences supérieures')? Or well-organised schemers ('cerveaux organisés')? Or bribery ('beaucoup d'argent')? Or the nastiness of the lower classes ('la mauvaise humeur de la populace')? Or the powerful people in the government itself ('gens puissans')? None of these: he thinks it was a natural response to each incident in the progress of the riot ('il nait tout naturellement des incidens'). But what really does this mean? For historians this rephrases rather than answers the question: what is the relationship between the fact of the moral agency of individual people and the fact of the moral agency of groups of people, especially in group political actions? How does the autonomy of the person become assent to action with others? But Charron is historiographically well ahead of the first canonical work on crowd behaviour, by La Psychologie de foules (I895), by Gustave Le Bon (I84I-I93I), who thought crowds were all a matter of the power of numbers, the susceptibility of weak minds and contagion.

For the pre-Revolutionary French riots the subject was opened up by E. P. Thompson in I97I with his notion of 'moral economy'. ${ }^{5}$ By moral economy Thompson means moral judgements about economic matters, and for him the character of moral judgement is largely externalist and cognitive. The debate on the matter includes differing views about the nature of the information, beliefs and customs on which the rioters acted. ${ }^{6}$ However, better-informed views of the rioters' motivating stimuli do not further establish their moral autonomy. ${ }^{7}$ To know whether they were old-fashioned or newfangled, paternalist or revolutionary, is not to understand the moral force that grew from individual actors' commitments to mass action. The cognitive nature of their moral deliberation is clear, even though different people responded to different developments. The externalist and reductive parts of Thompson's moral economy and of later versions by others leave insufficient room for the internalism that a strong notion of moral autonomy requires.

In a I988 paper Colin Lucas comes closer to the question of the moral freedom of the crowd: 'It is this liberation of the traditional reflex that poses the principal problem of the crowd's transposition into the revolutionary environment and informs the whole question of its relation to revolutionary politics. ${ }^{8}$ Strikers and rioters, Lucas says, exercised a 'discourse of justice'. ${ }^{9}$ The suddenness in what Lefebvre in 1934 called 'a sudden mutation' of a crowd into a riot is located here: not so much in short duration of time as in the depth of internal deliberation that makes the stride from an experience to awareness of moral obligation, decisively crossing the line from an old habit to a new behaviour and from dilemma to choice. Between thought and action lies the vast distance of deliberation, some form of which appears in everything the human agent is capable of willing. Moral autonomy requires some notion of internal freedom, and it is into this sphere that discourses of the good most importantly enter, if they are to enter at all. The crowd comprises many such internal discourses, none of them immune to the outward world but all of them responsive to it on the basis of each agent's judgement of her own principles and of the values offered her in the words and actions of others. The moral life of crowds is not only about economics but also about the all-encompassing category of morality itself. It is their moral universe. ${ }^{\mathrm{IO}}$ 
In the pre-Revolutionary period increasingly brutal conditions threatened survival. But this does not mean, as Olwen Hufton says it does, that the need for survival negates all 'ethics' on the part of those whose lives are under threat. II We know that people often reaffirm or fall back on their morality when struggling with survival, often on the conviction, whether right or wrong, that their moral sense will help them to survive or to make choices best for the survival of others to whom they hold allegiances. Furthermore, the need to survive can generate a moral point of view - not merely by deeming 'moral' anything that helps one to survive but by stimulating a creditable, estimable morality serving the sense of justice that existential threats provoke, efficiently aiding in survival and, most importantly, illuminating moral choice. The existential need has been the source of sophisticated moral codes in part by prescribing judgements as to what is and what is not acceptable for the well-being of those who follow, to whom the moral code is handed. That this process is 'overcome' for the poor by the brutality of their lives is both dismissive of their moral agency - in any time and place - and an unhistorical understanding of the history of moral philosophy.

The rioters in pre-Revolutionary France certainly acted on the basis of moral judgements. But these judgements were not solely about markets, or about markets and 'economic norms and obligations, ${ }^{22}$ or about all these plus conservative or paternalistic sentiments that they held, or even about all these multiplied by the different situations in different localities and by the relations between the 'audience crowd alongside the acting crowd'. ${ }^{\text {3 }}$

Economic matters are not discontinuous with the other parts of moral life, nor are they the factual core on which moral deliberations, including feeling and conceptions, as well as actions, supervene. This is because the process of deliberating one's moral obligations, whether intellectually sophisticated or not, stirs up the long, rich archive of voluntary and involuntary memory that informs consciousness. Given the moral equality of all people, all people are more or less equally complicated in such responses to moral dilemmas and in the inward complexity of their deliberations. To say that the pre-Revolutionary rioting and striking crowds in France and the similar entities in England acted out of moral choices about the morality of their economic dilemmas has been one good step beyond viewing a rioting crowd as a diseased mob or as an instrument of a final purpose for society or for humankind or for time itself. It has also been a good step to say that survival is a defensible basis for developing moral thought. But it is a better and further step to look at the fullest range of the lives of the members of the crowd as members of their civilisation as well as of their own community, holding that only life as a whole is adequate to account for moral life. The history of ideas allows historians to see the diachronesis of the society on the wide civilisational scale. Intellectual history has, or can have, this moral purchase, that it is a necessary part in giving an account of the whole moral life of a person, a crowd, a movement, a society or an era.

In the cases of rioting crowds we have the transit, perhaps sudden but by no means shallow, univocal or even local, of moral notions between the individual and the group action. They make the transit by assent; the individuals and the group strive for assent by communication among a mass of people, which is necessary to most successful movements. These notions comprise both individual goods or rights and universal goods or justice. The notions that the rioting crowd opposed were also deliberated among those in power. Both sides developed their notions under the large-scale trends of their civilisation, though they were not wholly or minutely determined by these trends.

From late I785 to the first days of I786 the day-labouring porters experienced in their own affairs and in their own neighbourhoods a battery of endeavours to rationalise not only production but also their social relations and their way of living. Their riot in the first fortnight of the new year grew from some level of awareness of the operations of ratio in 
their moral universe. Many readers know the term ratio as a name for problematising rationalisation as the key force in Occidental history, advanced by Max Weber (I864-I920). Weber wanted to account for the inception, flourishing and decline of social organisation, which is perhaps the oldest task of historians, whether they see this cycle as eternal, dialectical or natural. His simple, intelligible idea was one of the strongest explanatory principles developed in modernist thought. Since Weber's time historians have come to realise that, while the effect he describes is true and profoundly important, ratio does not operate as an efficient cause as if it were a motor. For example, Michael Warner in the well-known first chapter of his Letters of the Republic powerfully argued that technology (such as the printing press) operates within a politics and not outside it. ${ }^{\mathrm{I} 4}$ Ratio also needs an 'epistemic base', in Joel Mokyr's useful phrase ${ }^{\mathrm{I} 5}$ - the shared body of knowledge that grows exponentially. But politics and epistemic base are not enough to fill out the notion of ratio as an operator in the growth of Occidental culture. As Valentin Groebner puts it in his groundbreaking book Who Are You?, documentary registration - and, as I see it, by implication, rationalisation in general - was a 'pragmatically deployed political instrument, not an agent of bureaucratic rationalization per se'. ${ }^{16}$ Some other part of the story is necessary for understanding rationalisation.

Ratio requires not only powers and objects; it also requires people to work on. This much may seem obvious. But if we are to take seriously the personhood of those people - our own personhood too - we must recognise them as actors in a process of friction between each agent and the crowd and between people and the larger forces at work. The only field adequate to such a process of friction - including economy, ratio, technology, knowledge, memory, history and everything else - is moral life in full. The friction, or conflict, in moral life is the dilemmas communicated in words, images and ideas and furthered in the projects and productions that ideas provoke. If people are the fodder that ratio needs, then it is people who can deny it fuel by realising their full personal moral agency as individual and as collective actors. The person as moral agent, as something other than subjectivity, is the way out of the circle of dominative power. The historian of ideas can help by accounting for the frictions among the parties to fundamental developments by means of the wide and intensive light that general conceptions shed on particular events.

\section{III.}

We can see the streets on which porters and police fought as they were when Charles Marville (I8I3-I879) photographed them between I865 and I869. Balzac described them in I835 as the 'most horrible' and 'most unknown' in Paris. ${ }^{\text {I7 }}$ In Marville's wide-angle albumen prints many of the buildings of the Faubourg Saint-Marcel and adjacent neighbourhoods in I786 still stand: Place Maubert, the centre of the neighbourhood and the starting-point of the revolt; rue Grenelle, up which men chased the officials who were the targets of their anger; and rue des Noyers, their half-secret back-door to the Faubourg Saint-Germain, by which they dodged police and ganged up. ${ }^{\text {I8 }}$ Partly because of the porters' revolt, rue des Noyers was destined to be destroyed by Haussmann, Marville's patron. ${ }^{\text {I9 }}$ The buildings are narrow - some just one window wide - with thin slices of chimneys, squeezed like bubbles or wedges by the curving old roadways or flattened back by the wide avenue. The streets and buildings look quiet and mostly empty, as if cleared of life in preparation for the renovations ordered by Haussmann. If we could see the quartier as it was in I785, we would, of course, see it in full colour rather than in black and white and grey, and with very many more signs for 
street names, cafés and limonadiers (who sold fortified spirits and other drinks); we would see the bakers, builders, tanners, textile workers and the traiteurs who provided the take-home food of the day; many carriages, carts, horses, dogs; the stalls, stairwells, water well-heads and small back courts in which people met; food, drink, talk; and movements cramming Place Maubert (smaller then than it is now) - the neighbourhood where sixty to sixty-five thousand people lived. The district to the east was industrial and poor. Tanneries filled filthy buildings along the Bièvre, which the Gobelins factory and the Jardin des Plantes also used. The streets to the south, in Saint-Jacques, near the Observatoire, were full of university students and teachers. It was a little newer, a little better off. To the west of the Place Maubert and its ancient narrow streets, old passages were ravelled together from centuries of use by the craftsmen and bourgeois who lived by their shops. People here generally comprised the most financially stable families in the area. $^{20}$ Saint-Marcel, the densely populated quartier surrounded by these other student and industrial neighbourhoods, had a tenth of the population of Paris ${ }^{2 \mathrm{I}}$ but about a quarter of the indigent in all Paris. ${ }^{22}$ In I743, fifteen to eighteen thousand parishioners in the quartier were indigent owing to age and sickness. ${ }^{23}$

The police reports refer to the rioters as Auvergnats and sometimes as Savoyards and natives of Picardy. ${ }^{24}$ Every year hundreds of Auvergnats trudged from their starving mountain home towns into Paris. ${ }^{25}$ Porters were generally held to be Auvergnats, as dictionaries and encyclopaedias attest, but at times 'Auvergnat' seems to have been idiomatically used by the police for anyone among the working class whom they suspected of criminal activity. ${ }^{26}$ The Auvergnats of Faubourg Saint-Marcel were, however, by no means rootless. The Auvergnats and others who came to Paris to live during the second quarter of the eighteenth century and afterwards, when the population of the country grew, came to stay. The men were not wanderers, and they rooted their families and relations in the city; their children were urban people, not rural. Their relations with one another in their corner of the great city in which they married and worked was one of the bases for the capacity for group action they showed in January I786.

The revolt is generally called a riot by the gagne-deniers, or the 'make-pennies'. Gagne-deniers were unsalaried manual labourers for hire by the day. They delivered small parcels, moved house, including furniture, and carried or dragged heavy crated goods for anyone who paid for it. The class included forts des halles working at the food markets, also accused in the police reports. Gagne-deniers did the hauling not proper to porters who specialised in goods such as hay and salt ${ }^{27}$ or not done by servants or assistants on wages for shops, such as the men crating a portrait of Louis XIV in Watteau's L'Enseigne de Gersaint (I720). They did tend to have fixed places of residence, but they were young, hard-worked and hungry. In July I789 six or seven thousand of them did what the hundreds in January I786 did not do: they set to pillaging. ${ }^{28}$

The police reports almost always describe the rioters as gagne-deniers and crocheteurs. The crocheteurs, or harnessed haulers, are not often mentioned by historians, however, but their trade merits more attention. If anyone other than a beggar was beneath the gagne-denier in the eyes of society and the police, it was the crocheteur. The crocheteurs, it seems, hauled whatever was too messy for anyone else to handle. They moved not parcels or crates but fardeaux - stuff that refused to make neat piles, things that were always tumbling off and falling away, such as sticks loose or in bundles. ${ }^{29}$

The crocheteurs used a device loaded with goods for drayage that was strapped to their backs. More precisely, the haulers were strapped to the device. The Encyclopédie describes this infernal machine. ${ }^{30}$ A crochet is a bracket, related to our words 'crook', 'crooked' and 'crack'. In seventeenth- and eighteenth-century French it named various appliances 
made of wood or metal parts shaped so as to hook on to other parts in order to complete a reinforced structure. ${ }^{3 \mathrm{I}}$ In the crochets of the porters, two thick vertical boards, bent to the human back like a horse's bridle, are braced together by two perpendicular boards, one placed against the shoulders and the other across the thighs. To these two boards, another frame of boards curving well away from the bearer is attached by nails and two sticks, one on either side, and a thick plank at the bottom. Additional lathed petits morceaux de bois reinforce it. The open-sided bin thus formed holds goods snugly up to its brim, just where the outside frame curves away from the inside frame. More goods are piled on top of these, higher than the hauler's head, and these are held in by straps tied from the top transverse plank to the topmost element of the outer basket. Buckled straps (brassières) harness the hauler. Since a man could not load up the crochet and then hoist it on to his back by himself, someone else, probably another crocheteur, loaded up the crochet on to a hauler, who then at once had to start to walk quickly to deliver the fardeaux.

An unattributed watercolour in the manner of Les Cris de Paris (c.I750-90) gives us some sense of the harnessed hauler at work (Fig. I ). ${ }^{32}$ We must read the image carefully, because the subject is made picturesque and rather neater than the original must have been.

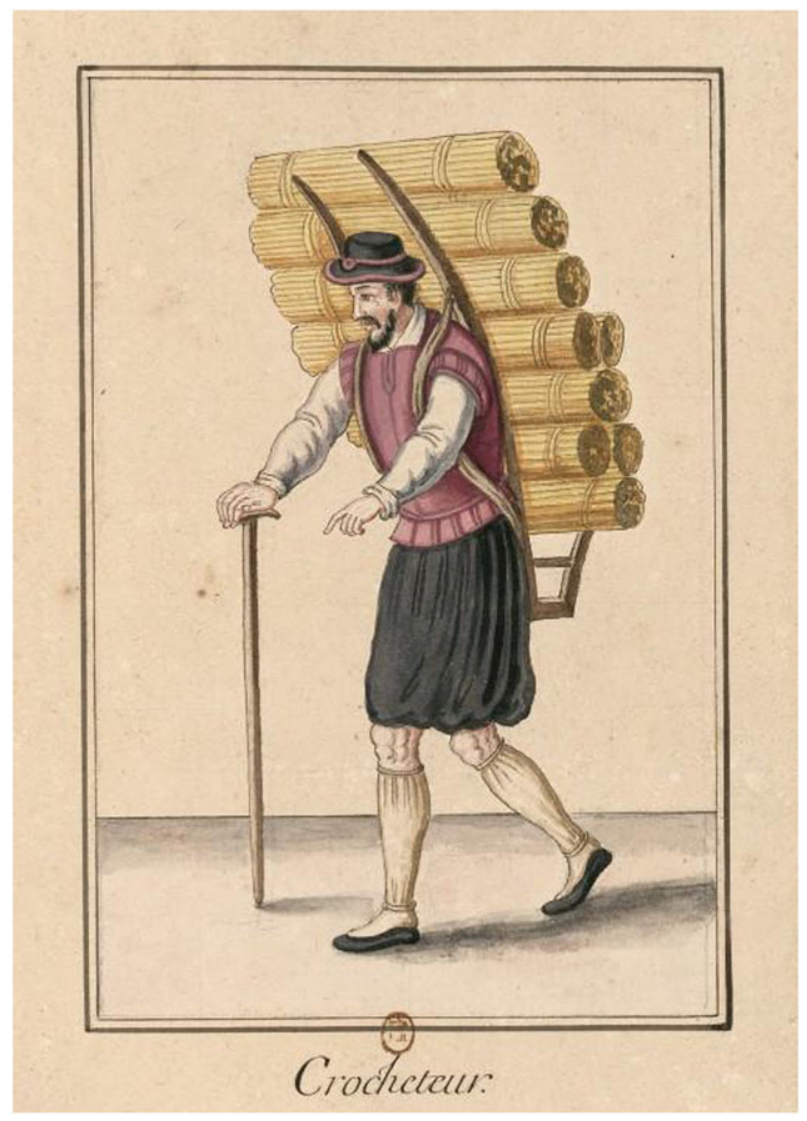

I. Crocheteur, undated (eighteenth century), Paris, Bibliothèque nationale de France (Bouchot, II58) 
Nonetheless, the artist has represented certain facts through, or perhaps underneath, the unrealistic drawing. The figure of the labourer draws the eyes downward to the ground, from the bow-shaped base of the crochet that pushes the bearer's back forward, to the downward palms, one of which clenches the stick the porter needs to keep from falling over, to the vertical strokes on his stockings that stand for stressed calf muscles. The man's knees are also deformed. Unless the artist imagined this detail, we see inflamed and severely calloused joints, perhaps rheumatoid, damaged from the years of hauling the crochet that threatened to topple man and burden at any moment while moving along the rough pavements and dirt around docks and warehouses and throughout the city. Think of an effect opposite to that of Daedalus' wings, likewise girded to his back. Daedalus' wings freed him aloft (for a little while), but the crochet was always just about to cause the wearer to fall flat on his face. This is a picture of great forces bearing down on each little person.

Unlike some servants who, depending on the fortunes of the families they served, retired as rentiers if they were thrifty - sometimes to a house in the country - make-pennies and harnessed haulers rarely retired. They worked as mules until they died, and they died young. The Abbé Galiani sadly noted that, despite their tendency to strike and riot, owing to their poverty, nothing ever really changed for them. ${ }^{33}$ They made up about I 5 per cent of elderly beggars in a sample surveyed in $1750 .{ }^{34}$ The waves of good ideas for public charity in the I630s and I760s created hospitals that served in the end to do little more than host those dying from hunger and disease. The repression of vagabondage as the worst of threats to public order, begun in France in the seventeenth century and reinforced in the next century, ${ }^{35}$ increased the suspicion and the pressures to which day-labourers were subject because the next step down in life, to mendicancy and vagrancy, meant mortally severe criminal punishment, such as La Bagne in Marseille (and the Arsenal in Venice). Hunger, as Piero Camporesi has shown, was not only disillusioning but also illusion-making, causing hallucinatory states among the famished. In addition, the hungry ate herbal substitutes for wheat and took herbals cures that were often psychoactive and toxic. ${ }^{36}$ The visions that resulted from chronic or episodic malnutrition or ingestion of psychoactive simples were sometimes dreams of better lives in a better sphere of reality. Camporesi says that the contrast could reveal to the hungry person the unauthorised truth about her oppression.

Paris displayed on its great stage the grandeur and the weakness of the society, its wealth and accomplishment and its awful need for material improvement and increased moral responsibility. In a village within the city, such as the Faubourg Saint-Antoine or the Faubourg Saint-Marcel, and within the circle of friends and relations from mountain home towns, and among the gagne-deniers and harnessed haulers - les hommes de peine waiting to be hired in the Place de Grève, at the Porte de Lyon and in les halles, in all these places the greedy, bustling great city was observed. The inhabitants knew the moral conflicts of the entire situation since they were embodied in the topics of daily discussion. ${ }^{37}$ The same was true for those who benefited from the situation: these too knew its failings in varying degrees and kinds of conscious certainty, just as the harnessed haulers knew that their load was not only too heavy but also unstable, unbearable, feasible merely for just as long as it took to get it off their backs at the intended destination or by accident and not for a moment longer. The heap of stuff a hauler delivered was thereafter inert, absurd and undesirable until necessity again required something to be transported. The crushing instability of the harness is a good signifier of the haulers' moral universe.

Other parts of that universe came from other parts of the society. Precarious situations gripped the top of the nation as well as the bottom. The financial sector expanded in the 
I780 at the cost of the production and distribution of goods and services. When bubbles on the Bourse burst, the ones who paid in the end were those who traded goods rather than those who traded money. For these latter, the agioteurs, there was always another paper fiction that made wealth. Although the financiers of the I780s did not bundle and securitise mortgages based on mendacious credit ratings, they went to similar lengths to profit from similar fictions. The government had poor tools of monetary policy and almost no actuarial tables or formulas of probability with which to respond. It was, in fact, merely one of the speculators. It conducted more than one bond issue as a lottery in which a few buyers could have the luck to win interest rates of 150 per cent per year and one could win 4 ,I66 per cent per annum. ${ }^{38}$ The financiers naturally combined here to catch the whole haul, having risked nothing since every bond brought a return. Similarly, syndicates of investors formed corporations to receive contracts from the government to perform essential services. It happened rather often that one corporation snatched the contract from its established holder by paying more to the treasury and promising better service or by bribing an official. The king wanted better services - everyone did, and everyone was in want of more money as credit hollowed out value. Thus the services required to produce and even to live were enfeebled, even if sometimes improved.

The porters were precisely targeted victims of such improvements built on deep bankruptcy. The simple act of standing in a public square to offer oneself for hire to deliver parcels, to carry loads of commercial goods and to move furniture and household goods from one house to another came under threat from the political, financial and commercial worries of the state. In October 1785 the government proposed a new régie for the organisation of these transport services. Instead of the direct, personal hiring of day labour on the spot, which involved people seeing and being seen by one another, and which also was fraught with theft, fear, arrogance and abuse, the government decided to pay a corporation to specialise in the more efficient organisation of these services. Those who wished their parcels, goods or household to be transported were to contact one of the ten agencies of this corporation located in central Paris. Its drivers, in uniform and red coaches with medallions, were to do the work, using more than a hundred depots as sorting stations or exchanges to quicken the work, to prevent loss and theft and to provide a more reliable service by regularly employed labourers. ${ }^{39}$

Since the preceding century entrepreneurs had competed in Paris to provide messenger, mail and delivery services. ${ }^{40}$ Some held contracts for years; others quickly sank. The state's interest in greater revenues tended towards creating central a private monopoly, because such an enterprise could advance more capital. Turgot centralised the postal service in I775, putting the state in control of it through its contracts for the work with private enterprises. ${ }^{4 \mathrm{I}}$ In 1780 the small services were paid to shut down in favour of a Grande Poste that operated until the last day of $\mathrm{I} 783,{ }^{42}$ when Jean Lanchère et fils bought the contract for Paris, Versailles and Sèvres for 80,000 francs. ${ }^{43}$ The plan of I786 was intended to be undertaken nationwide not only on account of inadequate revenue or faults of the old services but also in a move to improve the entire commercial infrastructure of the nation. ${ }^{44}$

Of the ten agencies, seven were on the right bank of the Seine and three on the left. ${ }^{45}$ The seven right-bank offices comprised one to the west of the Palais Royal, three to its north and three to the east along the river. The left-bank agencies lay between SaintMarcel and the Luxembourg to the south-west. To a considerable degree this network of redoubts reflected property development heading out of the Marais and away from the central markets. Property there lost value, and speculators chased after investments elsewhere. ${ }^{46}$ Old cemeteries - notably the des Innocents - were built over, improved lamps chased away the night, structures were given street numbers. The bourgeois were moving 
into new neighbourhoods, and the state encouraged and accommodated the new property development that this entailed. At the same time the city put its guard up, since one reason for its existence was to shut wild brigands and vagabonds out of the gates: the ten famous octroi were built at the perimeter of the developing, expanded Paris. Trade was to be better taxed in order to support the government that was supposed to support society and the state. Thus fifty-four new customs posts appeared at the Paris periphery. They were to bring cash to the king but also, in theory, to stand for the moral obligations and benefits of being his subjects.

Some scientific activity at the service of the state was also part of the moral universe in Saint-Marcel. On I5 October I785, in the same month in which the state moved to contract a new private administration for portage, the king of France commissioned Edmé Verniquet (I727-I804) to survey the entire city of Paris - every street, every cul-de-sac, every carrefour, the riverbanks, everything - and all the principal buildings in the city on a scale of 6 lignes par toise against a perfect grid. This idea, which went far beyond Turgot's map of I734-6 in making the city into a rationalised form of knowledge, was first suggested in September I 783 by the secretary of the Indentance de Paris, Nicolas César de L'Etaing. It was urged on Charles-Alexandre de Calonne (I734-I802) by the inspecteurgénéral de la voirie (the official in charge of roads and highways) in September I785. Political and commercial productivity require knowledge of infrastructure. Verniquet was hired for 600,000 francs to collect and to display this knowledge in trigonometric and cartographic form. By August I788 he gave them the completed project, comprising more than six thousand maps. ${ }^{47}$

Verniquet's work was carried on at night, making an ideally quantifiable city. This kind of city did not sit lightly on the old one of stone and wood. Through it one could see Paris as a coordinated grid of optically and mathematically analysed points. But the fact that this new vision was a secret shows anxiety about its significance to those by whom it was not meant to be seen. In the midst of this almost comically intense coordination of knowledge and power, the Faubourg Saint-Marcel had a special place. Verniquet's trigonometric operation required a ligne de verification from which all measurement against the meridian could be calculated. The meridian was given by the mapmaker's projection of the globe, but the line of verification was given by the built city. Verniquet measured the built, lived city in alignment with a straight oblique he found linking seven points, most of which were major structures. The two central points of this line, to the south of the northward three and to the north of the southward three, are the Observatoire Royale, which at the time abutted the Jardins de Luxembourg (both to the south-west of Saint-Marcel) and the south tower of Notre-Dame, which looms above Saint-Marcel just across the river. ${ }^{48}$ Thus the trigonometric order of Paris was centred right beneath the feet and above the heads of the people of the quarter in which the greatest concentration of porters and haulers lived. Each of their back courtyards and alleys and corners was brought silently under surveillance in the autumn of I $785 .{ }^{49}$

The gagne-deniers and crocheteurs of Paris during October, November and the freezing December of 1785 were caught in the moral conflicts consequent to the increase of knowledge and wealth among those with access to these goods. Some of these conflicts entered the moral world of the rioters from even further away than Parisian finance, politics and science. Coming from the large transatlantic trade, they were brought to bear in France in good measure through the incessant activity of one busy man: the ministerplenipotentiary of the United States, Thomas Jefferson (I743-I826).

Not long after his arrival in Paris, as the first ambassador to his nation's first ally, Jefferson was concerned about the means of commerce, transport and post between 
France and America. The two countries established a regular seaborne mail service in I783, directly after the final success of the American Revolution. But soon 'The derangement of the Packets has discouraged me quite', Jefferson wrote to James Madison on 30 August I785; he hoped to 'See their number restored. Some Evil Genius thwarted this simple and usefull Idea. ${ }^{50}$ Letters dated I3 July did not get to Paris until 9 September. ${ }^{5 \mathrm{I}}$ On the same day he wrote to John Jay about a French proposal for arranging frequent and regular mail packets to remedy this problem..$^{52}$ Jay replied on II November that he had 'for some Time past been looking in vain for a french Packet' in order to read 'Late Advices of the Algerians having commenced Hostility against the United States' ${ }^{53}$ This proposal for regular service came to Jefferson from Vergennes in May I785 and was submitted to Congress on 29 March I786, Adams having agreed that the power to regulate commerce was to be vested in Congress by the constitution. Meantime, an arrêt of I 4 December I785 established regular transport of mail, goods and people by twenty-four paquebots from Le Havre and Bordeaux to America. ${ }^{54}$

This was in the same month in which the new Parisian monopoly was authorised. These developments show the larger frame around postal and transport reform in France, not only as to dates but also as to scope. For in these months Jefferson was negotiating the Treaty of Alliance, which supported the enlargement of the two nations' transatlantic trade. Convinced that British hostility to America was implacable, Jefferson saw that America needed French partnership and infrastructure for its European commerce. ${ }^{55}$ He negotiated a commercial treaty with Portugal in this period as well. Furthermore, the Treaty of Alliance was necessary, he believed, to secure the ratification of the constitution by the states. He nurtured the power of the American economy and society in Europe. The old world was entering into a different relationship with the new.

In the last quarter of I785 the infrastructure for international transport took what seemed to be a step forward partly in response to the formation of the United States. While this was afoot, the Calonne government proposed and adopted the new post and transport service in Paris. Ideological and commercial affairs of the wider world were bearing down on the make-pennies and harnessed haulers of the Place Maubert. The events were economic and social in part. They probably also appeared in conversations in the neighbourhood, ranging from gossip about scandals and the price of bread to intellectual movements, the philosophical language of which seems to have penetrated most areas of French life. ${ }^{56}$ Messages, messengers and mail brought facts, rumours, good news and fear of plagues; these were issues of the moment as well as systems of communication in the developments leading to the porters' strike of January I786. The balance of that moment was something larger, even greater: a correlation of moral forces to which each actor responded, exercising, defending and seeking power but also doing these things in order to care for himself and others. The state was trying to provide the structure the economy needed even where the religious establishment had for centuries prohibited it: in I787 an edict authorised non-Catholics to establish their legal personhood before a judge (or curé) and thereby obtain liberties, ${ }^{57}$ including that given by the possession of a passport under the system begun in 1669 by Louis XIV. ${ }^{5}$ The passport, as much as anything else, can represent the stressful combination of liberty and restriction that state authority bestows.

The pressures of the human situation specific to the lives of the porters were growing. Each spot on the ground of the faubourg witnessed the conflict of ideas about the value and future of human life. In January I786 a better parcel-post service, a better urban administration and wider international trade threatened to depress the wages of the poor, to whom no penny came without toil, at the same time as it offered the prospect of increased prosperity to others. Better communication and growing accumulation, storage 
and analysis of information increased the state's ability to act on behalf of, and also upon, its citizens..$^{59}$

As of the beginning of I786 these men found no jobs offered to them on the streets where they used to wait for work. The private monopoly under contract to the government was now the only authorised provider of the services they had provided. Wealthy men invested in this enterprise, both as financiers and as managers: Louis Auguste Le Tonneiler de Breteuil ( $\mathrm{I} 730-\mathrm{I} 807$ ), as the commissioner of police in Paris, among his many other offices, was one of them. The enterprise hired people other than the free labourers whose kind had worked the docks and the warehouses for at least two centuries. The ability of the Auvergnat, Picard and Savoyard men to help their own and one another's families survive vanished on the coldest, hungriest days of a dreadful winter. Schooners and packets stimulated trade; trade needed regular and reliable transport; transport even of household goods was now under the surveillance of corporatised public authority; authority had come to rest on wobbly bonds and stock shares; and the men of credit (having it or seeking it) needed efficient and cheap labour. For this they needed ideas that had the power to organise the world and point in the right direction, within which were potent notions of their own capacities and liberty to seek wealth and through wealth to seek better lives.

IV.

The porters took quick action after the new contractors began post and transport services on I January I786. Christmas and New Year's Day were freezing cold. Blocks of ice clogged the Seine. In these circumstances the men needed work without delay, and yet the possibility of work and bread had disappeared in a hurry with the passing of the old year. They must have sensed the larger forces pulsing through their streets, their society, their nation and even in the world. The unlettered are as perceptive as the learned are, often quicker; and the French poor were more alert to innovations than were many of those more comforted by their present circumstances. Although few porters might have known who Thomas Jefferson was or what a cadastre is, they knew the threats afoot against their way of living. In January they behaved with unexpected solidarity, inspired perhaps by the professional relations of artisans. No observer seems to have anticipated the strike, much less the remarkable development in its second and concluding phase.

In the early morning of Monday 2 January the management of the new package service at the office in the rue de la Verrerie dispatched one of its bright red coaches to be loaded with goods at the quai Peltier. On the his way to his destination, at the corner of rue St-Jacques-de-la-bucherie and rue Saint-Séverin a small group of gagne-deniers and crocheteurs began to shout at the coachman. They were as young as twenty-two and as old as thirty-nine, their leader a man named Maréchal. They assaulted the coach. By mid-morning two to three hundred porters gathered and were rioting at the intersection, beating and kicking coachmen, overturning the red coaches in the rue Galande, rescuing their comrades from arrest, retreating and also spreading disorder up the rue des Noyers towards the Faubourg Saint-Germain. A gang of forty to fifty other men started fighting on nearby streets. There was, the police wrote, a 'tumulte considerable' for more than an hour, along with many smaller affairs. ${ }^{60}$ The rioters attacked the coach and then the police with huge sticks and boards. They wounded some police. The police drew swords and finally arrested six men, who were taken to Châtelet; the proper rewards were 
paid to the arresting officers. But the mob, 'si furieux', did not disperse. ${ }^{61}$ Five hundred, with whatever weapons came to hand, moved angrily in the streets near the Pont de la Tournelle. Two to three hundred men again gathered in front of the house of the district intendant. There, in a manner that might have reminded everyone of the mob's relentless pursuit and killing of a policeman commonly believed to have kidnapped, under colour of authority, children who were sent to populate the Mississippi colony in $1750,{ }^{62}$ the crowd demanded the release of those who were under arrest. Shopkeepers told one another that even the police could not resist the fight the crowds were giving. ${ }^{63}$ Nonetheless, by nightfall the fighting stopped. There is no report of action in the next seven days.

On Wednesday Io January they tried a different tactic. Somehow these people arranged to walk together to the Palace of Versailles in order to present their cause to the king. ${ }^{64}$ There was, in Hardy's words, 'l'espèce d'émotion générale des gagne-deniers'. Knowing of this in advance, the authorities planted troops to thwart the crowd at various points west to the Pont-Neuf and Saint-Honoré and to the south-west. Nonetheless about one thousand men and women arrived together at the gated park of Saint-Cloud by about noon. The guards and the porters negotiated a deal. Twenty-four of the porters were allowed to advance to the first gate of the palace. They did so. Then twelve were allowed through into the forecourt, and they did so. Finally, six representatives were permitted to pass the second gate and approach the ground-floor gallery. After three hours an officer of the guard announced that the king was not present but that they were allowed to leave their placet 'pour qu'on ne manqueroit pas de remettre entre les mains de Sa Majesté et sur lequel ils auroient réponse dans la huitaine, discours au moien duquel, on les avoit engagé à s'en retourner'. ${ }^{65}$ Thus they completed their protest and left. Their grievance was granted the minimal conceivable efficacy: it was not to be given to the king or his representative or received by them but rather was left where the king would not fail to find it and would then surely read it out of his abundant care for his people. From this flowed the promise that he would reply, based on the common political understanding plus the personal concession by the protesters, through their representatives, that Louis was a good ruler who could not help but consider the pleas for justice that his people had the right to make to him and to which he had the obligation to respond.

This civil right and its corresponding monarchic obligation are, as Yves-Marie Bercé pointed out, an ancient part of governmental compacts. ${ }^{66}$ They had traditional usages in France. In this regard, the marchers' expectation of justice showed their commitment to the feudal monarchy. As in many mythic tales, the heroes progress in three stages, each one closer to the seat of magic or justice. ${ }^{67}$ Some old stories take place within castles and temples, just as this does, moving from outer wall to inner court and sanctum. The brave and worthy become fewer, halved each time. Such was the narrative that majesty demanded of subjects who, in performing it, made deeper obeisance to the throne at each stage. Their submission was also narrower: more of the people stood aside, both acquiescing and reserving themselves; the remnant gained power by the arrangement until they were the tip of the spear, lowered to the ground by the truce. Royalty set the terms in this negotiation. But that the parlay should have happened at all was the remarkable thing. For never before had a crowd of the dispossessed, organised as a power to be reckoned with, successfully aimed itself at the palace of Versailles. ${ }^{68}$

The king did not answer the placet. He was indeed at Saint-Cloud that day, where he attended the night ball given by his pregnant queen and the Duchesse de Polignac in the heated wooden rooms built for winter dancing. The Marquis de Bombelles wrote on II January that 'this evening's ball at the palace was not affected by this ridiculous revolt; 
people danced with the greatest gaiety' ${ }^{69}$ The king's government was fully occupied with its desperate financial affairs. The authorities punished five of the rioters by public humiliation and suspended sentences to the galleys.

\section{V.}

Robert Muchembled says that gestures represent 'social friction' and are 'codified to induce an expression of respect, a demand for consideration, or even a desire for confrontation. $7^{\circ}$ The spear-tip shape of the advance of the strikers into the royal space displays the friction between the people in the crowd and not only the leading figures but also the leading concepts in the society and state growing around them. They were frightened by the changing moral order shaped by the conceptual current of the rationalisation of life; this is what threatened their survival. The march out of the quartier was rare enough, the march to Saint-Cloud nearly unprecedented. This violation of spatial boundary mirrors the conceptual purchase of the régie of dispatch centres, Verniquet's grid map and global trade. The strikers left their borders, just as capital, information and the nation itself were doing. They went out not to join this rationalising power but to petition it. Their successors debated it and finally fought it.

This quasi-mythic rite of the porters' penetration through les grilles to the sacred sovereign expresses a view of moral relations in society deeply contrasted to that of the new economic and administrative order then under construction. The march to the power of justice itself was hierarchical, moving from the earthly mass up through the spheres to the supernatural. This was not the planar world of Verniquet, nor the amoral open market of financing, nor efficiency-first, on-time goods delivery, nor the interconnected world of global enterprise, nor the form of democracy under construction in America. It was something that had a higher hope. The moral world of the marching porters - the universe of the good and of goods, of justice and right, and of the opposites of these - was both conservative and revolutionary, as has often been noted. It also looked both backwards and forwards to protests both more violent and organised at a higher level than France had hitherto seen. It was smaller than the dreadful riots of I775, but in August I786 a large and violent protest by textile workers in Lyon broke out. Plagues had swept southern Italy a few years earlier, so these too the people talked about and feared, along with starvation due to bread price rises. Kings, stock speculators, ambitious businessmen, engineers, mailmen, gagne-deniers and crocheteurs feared what people usually fear; and life seemed to become harder rather than easier to sustain. They would have to fight harder - or to struggle to find deeper compassion than the old and new orders required of them.

\section{NOTES}

I. The primary source is file Y I28I6 in the Archives Nationales, hereafter cited as 'Y I28I6'. I examined a set of high-quality photographs of the complete content of the dossier; and I follow the pagination written on the leaves of the dossier in a later hand. Marcel Rouff examined the police dossier in I9IO and wrote the only comprehensive account of the porters' strike, 'Une Grève de gagne-deniers en I786 à Paris', in Revue Historique I05:2 (I9IO), p.332-47. Rouff's account remains a good source. Although he did not have the benefit of later economic and demographic studies, he needed no tutoring as to the misery of the lives of the poor, having written a book on coal-miners in the ancien régime. Later scholars follow Rouff and also directly cite the dossier in very brief accounts, including, among others: Haim Burstin, Le Faubourg Saint-Marcel á l'époque rèvolutionnaire: structure économique et composition sociale (Paris: Société d'Etudes Robespierristes, I983), p.325-32; David Garrioch, Neighbourhood and 
Community in Paris, I74O-I79o (Cambridge: Cambridge University Press, I986), p.I245; and Jeffrey Kaplow, The Names of Kings: The Parisian Laboring Poor in the Eighteenth Century (New York: Basic Books, I972 ), p.39-40. Beside the police dossier, the most commonly cited account is that of Hardy, Mes Loisirs [...], of I786, entries no. 3, 7, I3, I4, I9 and 23; also no. 60, referring to a printed account I have not yet been able to track down. The chief printed source is the Mémoires Secrets, attributed to Louis-Petit Bachaumont, among others (London [?Amsterdam], 'John Adamson', I783-9), vol. XXXI, for I786, entries 2 January (p.7), 3 January (p.9-Io), 4 January (p.II-I3), I2 January (p.28-9) and 20 January (p.49-50); see also vol. XXX, for I785, p.Io9.

2. J[oseph] Charron, Lettre ou mémoire historique sur les troubles populaires de Paris, en août \& septembre I788, avec des notes (London [?Paris], I788), p.4I-5ff. Charron argues that artisans switched from their own traditions to trades in which they were not competent in order to move up in the world, becoming poor instead and sending their daughters into prostitution. He is particularly hard on street performers as a source of immorality.

3. This is the Burke of The Reflections, in the mildest phase of his response. As a matter of political psychology he is primarily focused on the operations of desire in those who led the crowds, though he eventually applied the same analysis to those whom they led. Strangely, some of the historians who have argued, against François Furet's revisionism, that the Revolution was ultimately turned into a counter-revolutionary re-establishment of the hegemony of moneyed interests, such as Florence Gauthier in her Triomphe et mort du droit naturel en Révolution, I789-I795-I802 (Paris: Presses Universitaires de France, I992), agree with Burke that a newer corrupt clique displaced an older one - though this is not to say that Gauthier and others are wrong in their views, since the claim that new forms of economic forces crushed the natural rights tradition is clearly established by the development of European society and culture in the nineteenth century.

4. Charron, Lettre, p.II-I5, including the long footnote.

5. 'The Moral Economy of the English Crowd in the Eighteenth Century', Past and Present 50 (I97I ), p.76-I36. He attempts to improve on Georges Lefebvre, 'Foules révolutionnaires', in his Etudes sur la Révolution française (Paris: Presses Universitaires de France, I963), p.37 I-92, who regards the rioting crowd as neither a group of individuals nor a herd but a remixed aggregate of pre-existing 'elements of mentality'.

6. For example, John Bohstedt, 'The Moral Economy and the Discipline of Historical Context', in the Journal of Social History 26:2 (Winter I992), p.265-84.

7. Bohstedt, 'The Moral Economy', p.270, says the rioters were both 'morally autonomous and strategically adaptable'. Whether it is possible to be both depends on the strength of one's notion of autonomy.

8. Colin Lucas, 'The Crowd and Politics between Ancien Régime and Revolution in France', Journal of Modern History 60:3 (I988), p.434.

9. Lucas, 'The Crowd', p.436.

IO. I owe the phrase 'moral universe' to one of my anonymous readers.

II. Olwen H. Hufton, The Poor of Eighteenth-Century France, I75O-I789 (Oxford: Clarendon Press, I974), p.367.

I2. Bohstedt, 'The Moral Economy', p.265.

I3. Lucas, 'The Crowd', p.427.

I4. Michael Warner, 'The Cultural Mediation of the Print Medium', in The Letters of the Republic: Publication and the Public Sphere in Eighteenth-Century America (Cambridge, MA: Harvard University Press, 2009), p.I-33.

I5. Joel Mokyr, The Gifts of Athena: Historical Origins of the Knowledge Economy (Princeton, NJ: Princeton University Press, 2002).

I6. Valentin Groebner, Who Are You? Identification, Deception, and Surveillance in Early Modern Europe (New York: Zone Books, 2007), p.I67-8. This work provocatively and authoritatively opens 
up the issues concerning identity and documents verifying identity in the development of early modern Occidental concepts of the self.

I7. As quoted from Père Goriot by Bertin, Le Faubourg Saint-Marcel, p.29, n.5 .

I8. See Anne de Mondenard, Peter Barberie, Franois Reynaud and Joke de Wolfe, Charles Marville: Photographer of Paris (Washington, DC: National Gallery of Art, 2013) - the first full catalogue and comprehensive exhibition of Marville's work. It includes his images of the tanneries along the Bièvre in plates 5I-4. Marville's images of three streets that prominently figured in the porters' strike are not included, but they are to be found online for an exhibition in August 2012 by the New York dealer Charles Isaacs

(http://www.charlesisaacs.com/exhibitions/exhibit_info.php/ı2), as follows:

Place Maubert at http://www.charlesisaacs.com/exhibitions/large.php/12/3/13;

rue Galande at http://www.charlesisaacs.com/exhibitions/large.php/I2/3/7; and

rue des Noyers at http://www.charlesisaacs.com/exhibitions/large.php/r2/3/2.

I9. The rue des Noyers, which opened from the west into the southerly end of Place Maubert, was absorbed into the boulevard Saint-Germain in I855. Rue Domat, called rue du Plâtre in I786, runs roughly the same route just north of the old rue des Noyers.

20. Burstin, Le Faubourg Saint-Marcel, p.288-93.

21. Burstin, Le Faubourg Saint-Marcel, p.67.

22. Burstin, Le Faubourg Saint-Marcel, p.270-7I, and George Rudé, The Crowd in the French Revolution (Oxford: Clarendon Press, I959), p.I7.

23. Kaplow, The Names of Kings, p.8.

24. Yı28I6, p.I, 5, and passim.

25. Rudé, The Crowd, p.I9; cf. the map in Robert N. Schwartz, Policing the Poor in EighteenthCentury France (Chapel Hill, NC: University of North Carolina Press, I988), p.I67, fig. 6.I.

26. Kaplow, The Names of Kings, p.28-9.

27. Kaplow, The Names of Kings, p.4I.

28. Une révolution à l'oeuvre: le faubourg Saint-Marcel (I789-I794) (Seyssel: Champ Vallon 2005) by Haim Burstin, whose discussion of the I786 porters' strike is referred to above, is an authoritative account of Saint-Marcel during the Revolution itself.

29. César-Pierre Richelet, Dictionnaire françois [...] (Amsterdam, I706), p.I73.

30. Denis Diderot and Jean le Rond d'Alembert, Encyclopédie (Paris: Briasson, David, Le Breton, and Faulche, I75I-65), vol. IV.50o, with original language and terms but also drawing from earlier printed accounts. Cf. Antoine Furetiére, Dictionaire universelle [...] (The Hague, I7OI), vol. I, 'crochet' and 'crocheteur'; Jacques Savary des Brûlons, Dictionaire universel de commerce [...] (Geneva, I742), vol. I.799 and I.I2II; Dictionaire universel des arts et des sciences (Paris, I732), vol. I.I35, I.299. Cf. also Savary, Dictionaire universel de commerce [...] (Amsterdam, I726), col. II95; and the remarkable description of the crochet as a 'machine très commode' in Jean-Baptiste Robinet, Dictionaire universel de science (London and Paris, I782), vol. XXI.445.

3I. For example, 'crochets de serrures' etc. in Dictionaire de l' Académie française (Paris, I762 ), vol. I.445.

32. http://gallica.bnf.fr/ark:/I2I48/btvi b6935262I .r=.langEN [accessed I4 June 20I5].

33. In his Dialogues sur le commerce des bleds (I770).

34. Kaplow, The Names of Kings, p.I32.

35. Schwarz, Policing the Poor, p.I8 describes the edict of I66I against fainéants; see also p.I2 and p.I6I. Arlette Farge, Subversive Words: Public Opinion in Eighteenth-Century France, translated by Rosemary Morris (University Park, PA: Pennsylvania State University Press, I995), mentions the sweep of vagabonds in I7I9 who were sent to Louisiana and Mississippi (p.II) and points out that the suppression of the Jansenists removed the best care-givers from the poor hospitals (p.48ff.) 
36. Piero Camporesi, Bread of Dreams: Food and Fantasy in Early Modern Europe, trans. David Gentilcore (Chicago, IL: University of Chicago Press, I989).

37. Charron, Lettre, p.I6-I8, affirms this.

38. George V. Taylor, 'The Paris Bourse on the Eve of the Revolution, I78I-I789', in The American Historical Review 67:4 (July, I962), p.958.

39. Cf. Hardy, Mes Loisirs, no. 23, and Mémoires Secrets, vol. XXX.Iog.

40. Paul Marchand, Le Maître de poste et le messager: une histoire du tranport public en France au temps du cheval, I700-I850 (Paris: Belin, 2006), p.54-5.

4I. Marchand, Le Maître de Poste, p.33.

42. Marchand, Le Maître de Poste, p.II6-I7.

43. Marchand, Le Maître de Poste, p.293-30I.

44. See also Eugène Vaillé, Histoire générale des postes françaises, vol. VI, pts I and 2. La ferme générale et le groupe Grimod-Thiroux (I738-I789) (Paris: Presses Universitaires de France, I947-55), vol. VI, pt I, p.IO3ff.

45. These offices were opened on 23 November 1785.

46. Daniel Roche, The People of Paris: An Essay in Popular Culture of the I8th Century, trans. Marie Evans and Gwynne Lewis (Berkeley, CA: University of California Press, I987), p.34 . See also David Garrioch, The Making of Revolutionary Paris (Berkeley, CA: University of California Press, 2002), for a description of the effects of the Parisian property development on the poor.

47. Jeanne Pronteau, Edme Verniquet (I727-I804): architecte et auteur du 'grand plan de Paris' (I785-I79I) (Paris: Service des Travaux Historiques, I986), p.3I5-I8, $335 \mathrm{ff}$.

48. Pronteau, Edme Verniquet, p.359-60 and 370, fig. I02.

49. Roche, The People of Paris, p.23I , refers to these changes as intended to be 'a more rational approach to deciphering space'.

50. Thomas Jefferson, Papers, ed. Julian P. Boyd et al. (Princeton, NJ: Princeton University Press, I954), vol. VIII.450.

5I. Jefferson, Papers, vol. VIII.472.

52. Jefferson, Papers, vol. VIII.453-4. (Jefferson writes that Franklin had not heard of this proposal.)

53. Jefferson, Papers, vol. IX.8.

54. Vaillé, Histoire générale des postes françaises, describes this negotiation in detail at vol. VI, pt 2, p.642-56.

55. Jefferson, Papers, vol. IX.446, and passim.

56. Jean Nicolas, La Rébellion française: mouvements populaires et conscience sociale (I66I-I789) (Paris: Editions du Seuil, 2002), p.30I-2.

57. Gérard Noiriel, 'L'identification des citoyens: la naissance de l'état civil républicain', Géneses I3 (Autumn I993), p.4.

58. John Torpey, The Invention of the Passport: Surveillance, Citizenship and the State (Cambridge: Cambridge University Press, 2000), p.2I .

59. Noiriel, 'L’identification', p.I7.

60. Yı28I6, p.I, 2, 5, 7, IO, 23 and 26.

6I. Y I28I6, p.29.

62. Arlette Farge, Fictions of the French Revolution (Evanston, IL: Northwestern University Press, I99I).

63. YІ28I6, p.44.

64. The question of the means by which le canaille organised their march to Versailles is an interesting one. In French villages the tocsin was rung to assemble people for demonstrations that became food riots. Sometimes groups picked up numbers as they marched from town to town, relying on their own noisy movement to communicate their issue to possible supporters. Sometimes documents supposed to portray the perfidy of the object of the strike were passed around. And, of 
course, both men and women could spread the word very quickly by talking to others (cf. Lucas, 'The Crowd', p.422-3.) These and other actions were means of communication employing oral and written words, sounds and sights to stir feelings and to manifest the moral integrity of the cause. In asking who started riots and how they spread, Charron asked exactly this question in I 788 about communications among rioters.

65. 'So that he would not fail to put it into the hands of His Majesty, and about which they would have a reply within a week or so - a statement for which they committed themselves to return.' Hardy, Mes Loisirs, II January I786, no. I4 (my translation).

66. Yves-Marie Bercé, Revolt and Revolution in Modern Europe: An Essay on the History of Political Violence (New York: St Martin's Press, I987), p.4ff., 3I and I99.

67. In Vivant Denon's erotic tale Point Lendemain (I777) the lovers reach their climax (such as it is) upon entering the third and innermost secret bedroom.

68. In the 'Flour Wars' of I775 a mob did assemble at Versailles, but it was mollified by concessions from the mayor of Versailles.

69. As translated and cited by Philip Mansel, The Court of France, I789-I830 (Cambridge: Cambridge University Press, I99I), p.5 .

70. Robert Muchembled, 'The Order of Gestures: A Social History of Sensibilities under the Ancien Régime in France', in Jan Bremmer and Herman Roodenberg (eds), A Cultural History of Gesture (Ithaca, NY: Cornell University Press, I99I), p.I3I-2, quoting an earlier work of his own.

BENNETT GILBERT is a historian of ideas and a philosopher. His work focuses on moral philosophy in the theory and practice of history and on the history of communication. He specialises in the intersection of intellectual history and material culture in the pre-printing period and in the Rococo. He is currently an instructor in the Department of University Studies at Portland State University. 